\section{俩 Heighten Science \\ P U B L I C I T I O N S Corporation ISSN 2577-1469}

Short Communication

\title{
Stem cells in heart failure some considerations
}

\author{
Federico Benetti ${ }^{1 *}$, Natalia Scialacomo ${ }^{1}$ and Bruno Benetti ${ }^{2}$ \\ ${ }^{1}$ Cardiac Surgery and Regenerative Medicine Department, Argentina \\ ${ }^{2}$ Engenieer, Research Departament Regenerative Medicine Benetti Foundation, Alem 1846 \\ Rosario Argentina, zip 2000, Argentina
}

\begin{abstract}
*Address for Correspondence: Federico Benetti MD, Cardiac Surgery and Regenerative Medicine Department, Argentina, Email:

federicobenetti@hotmail.com

Submitted: 09 January 2018

Approved: 24 Jaunary 2018

Published: 25 Jaunary 2018

Copyright: @ 2018 Benetti F, et al. This is an open access article distributed under the Creative Commons Attribution License, which permits unrestricted use, distribution, and reproduction in any medium, provided the original work is properly cited
\end{abstract}

Keywords: Heart failure; Stem cells; Autologous stem cells; Embriofetal stem cell

Check for updates
Stem cell treatments depend not only on the type of cell to be used but also on the different implantation techniques. Intravascular cell injections are known to rapidly separate from the vessels. On the other hand, it is also well known that direct injection into the myocardium provides better coupling within the heart muscle. That were the cases of Embriofetal stem cell (HFDSC) or Autologous stem cells (ABMSC) in our experience focused on direct approaches. When we have to deal with different stimuli, such as parietal stress or direct myocardial injury leading to hemodynamic overload, the heart responds with hypertrophy, able to initially compensate for loss of function. Later, and over a long subclinical period, progressive dilation continues to be compensated for by varying degrees of hypertrophy.

In the final stage, as described by Meerson et al. [1], dilatation overcomes hypertrophy and changes in cellular organization appear, such as: 1) myofibrillar lysis; 2) Increased lysosomes; 3) Distortion of the sarcoplasmic reticulum; 4) replacement of myocardial cells by fibrous tissue. Simultaneously, capillary density and contractile reserve decrease, and diffuse myocyte necrosis is a characteristic of both idiopathic and ischemic dilated cardiomyopathy [2,3]. Therefore, idiopathic dilated cardiomyopathy can be described from a pathological point of view [4], as a dilated heart with hypertrophied walls; macroscopically the dilatation exceeds hypertrophy. Microscopically the heart is invaded by areas of interstitial and perivascular fibrosis, adjacent to necrotic areas and myocytes that may be atrophic or hypertrophic, with loss of the extracellular matrix. Cell therapy in these patients is directed at restoring and repopulating the myocardium, thus restoring lost function by supplying cells that are able to differentiate into myocardial cells.

The use of mesenchymal or stromal cells as precursors of non-hemopoietic tissues was first attempted by the German pathologist Conheim in 1867 [5]. It was later demonstrated in tissue cultures that they were able to form various tissues, such as bone, cartilage, muscle, ligaments, tendons, etc., and to intervene in tissue repair [6]. An extremely interesting study showed that stromal stem cells treated with 5 Azacytidine a week formed interconnected with micro-tubuli cardiomyocytes. After 2 weeks they begin to beat and this contraction becomes synchronous after three weeks develop natriuretic peptide and stained with antibodies against actin and myosin and have a potential for action of cardiac cells [7]. Trans-differentiation in the cardiac phenotype requires an adequate microenvironment. It depends on the cellular interconnection for the generation of cardiac transcription factors (GATA-4 and myocyte factor 2 that was also observed) [8]. This was also confirmed by other investigators, emphasizing the importance of intercellular integration of cardiomyocytes with trans-differentiated cells [9]. Among the various cell types studied, stromal stem cells were shown to have the ability to differentiate into muscle and vascular cells and produce angiogenesis. 
This work was conducted by Weisel and Lee of the University of Toronto in 1999 [10]. This differentiation in the myogenic lineage with the development of actin, myosin and tropomyosin was demonstrated, as well as the presence of Conectin 43, a protein responsible for cellular interconnection.

\section{Several mechanisms of action of stem cells have been proposed to improve cardiac function:}

1. Fusion and transdifferentiation: Fusion with local cells has been ruled out, and the attractive concept of stem cells that Trans-differentiate and cross the barrier has not yet been demonstrated. Perhaps the correct anatomical mechanism will be clarified when cell therapy can be used more as a bridge for heart transplantation and more biopsies can be performed to confirm the first observations.

2. Mobilization of cardiac stem cells: another theory proposes that implanted cells mobilize specific cardiac stem cells housed in the muscle that are capable of cardiac regeneration.

3. Angiogenesis: Implanted autologous cells induce significant angiogenesis; according to some, this would be the main mechanism.

4. Extracellular Matrix: In heart failure there is a net loss of myocytes plus a loss of matrix architecture, leading to dilatation. The implanted cells could stabilize the latter, preventing dilation and balancing the enzymes of generation/degradation. This is the mechanism believed to cause Chagas disease [11]. The clinical application of this treatment began in 2000, and cases have increased worldwide. Our case studies show that this is a feasible procedure, which has no surgical or immediately postoperative mortality.

Our prospective, randomized study in ischemic patients showed marked improvement in the ventricular ejection fraction and in the functional class in which they received stem cells compared to those undergoing revascularization alone [12,13]. There are recent confirmations of our initially experience with a similar surgical intramyocardial injections technique, with different adult cells and processes $[14,15]$. Also the initially results of most of the trials in Chronic Symptomatic Systolic Heart Failure patients are promising [16]. Although in acute phase shows no improvement, probably due to the technique used [17]. The findings from our initial experience clearly suggest that HFDSC transplantation improved cardiac function in patients with heart failure due to idiopathic cardiomyopathy and also decreased left ventricular diastolic diameter No rejection or malignancy reactions were observed in this group at 40 months [18]. We believe it is imperative and extremely important that more research and trials with different techniques and stem cells of all kinds or with the stimulation of the own ones are carried out in patients with heart failure to be able to determine the most appropriate treatment in this type of patients.

\section{References}

1. Meerson FZ. The myocardium in hiperfunction, hipertrophy and heart failure. Circ Reserch. 1969; 25: 1-163. Ref.: https://goo.gl/ZWF8iV

2. Zak R. Cardiac hipertrophy: biochemical and cellular relationships. Hosp Pract (Off Ed). 1983; 18: 85-97. Ref.: https://goo.gl/AVUL1h

3. Prosper F, Pérez A, Merino J, Gregorio R, Chachques JC, et al. Adult stem cells for myocardial repair. Basic Appl Myol. 2003; 13: 15-22. Ref.: https://goo.gl/yJtHWQ

4. Colucci WS, Braunwald E. Patophisiology of heart failure in Braunwald"s Heart Disease 5th edition Saunders company 1997.

5. Prokop D. Marrow Stromal cells as Stem Cells for nonhematopoietic tissues. Science. 1997; 276: 71-76. Ref.: https://goo.gl/JfAJZv 
6. Pittenger MF, Makay A, Beck SC, Jaiswal RK, Douglas R, et al. Multilineage potential of adult human mesenchymal stem cells. Science. 1999; 284: 143-147. Ref.: https://goo.gl/mzszL2

7. Makino S, Fukuda K, Miyoshi S, Konishi F, Kodama H, et al. Cardiomyocites can be generated from marrow stromal cells in vitro. J Clin Invest. 1999; 105: 697-705. Ref.: https://goo.gl/8F6TX2

8. Xu M, Wani M, Dai YS, Wang J, Yan M, et al. Differentiation of bone marrow stromal cells into cardiac phenotype requires intracellular communication with myocites. Circulation. 2004; 110: 2658-2665. Ref.: https://goo.gl/iiSDqg

9. Chedrawy EG, Wang JS, Nguyen DM, Shum-Tim D, Chiu RCJ. Incorporation and integration of implanted myogenic and stem cells into native myocardial fibres: anatomic basis for functional improvements. $\mathrm{J}$ of Thoracic and Cardiovascular Surgery. 2002; 124: 584-590. Ref.: https://goo.gl/nyJhHB

10. Pittenger MF, Bradley JM. Mesenchymal stem cells and their potential as cardiac therapeutics. Circ Res. 2004; 95: 9-20. Ref.: https://goo.gl/Hcthfk

11. Vilas-Boas F, Feitosa GS, Soares MB, Pinho-Filho JA, Mota A. Bone marrow cell transplantation to the myocardium of a patient with heart failure due to Chagas disease. Arq Bras Cardiol. 2004; 82 185-187. Ref.: https://goo.gl/XoWhvY

12. Benetti F, Viña RF, Patel AN. OPCABG plus simultaneous autologus stem cells implants TCTMD. com. 2003.

13. Patel AN, Geffner L, Vina RF, Saslavsky J, Urschel HV, Jr. Surgical treatment for congestive heart failure with autologous adult stem cell transplantation: A prospective randomized study. J Thoracic and Cardiovascular Surgery. 2005; 130: 1631-1638. Ref.: https://goo.gl/UayHSM

14. Comella K, Parcero J, Bansal H, Perez J, Lopez J, et al. Effects of the intramyocardial implantation of stromal vascular fraction in patients with chronic ischemic cardiomyopathy. J Transl Med. 2016; 14: 158. Ref.: https://goo.gl/Nvzyk1

15. Anastasiadis K, Antonitsis P, Westaby S, Reginald A, Sultan S, et al, Implantation of a Novel Allogeneic Mesenchymal Precursor Cell Type in Patients with Ischemic Cardiomyopathy Undergoing Coronary Artery Bypass Grafting: an Open Label Phase Ila Trial. Journal of Cardiovascular Translational Research. 2016; 9: 202-213. Ref.: https://goo.gl/TCPQTo

16. Poulin MF, Deka A, Mohamedali B, Schaer GL. Clinical Benefits of Stem Cells for A Systematic Review of the Existing Data and Ongoing Trials. Cell Transplant. 2016; 25: 1911-1923. Ref.: https://goo.gl/HJs294

17. Traverse JH, Henry TD, Pepine CJ, Willerson JT, Chugh AR, et al, The TIME Trial-Effect of Timing of Stem Cell Delivery Following ST-Elevation Myocardial Infarction on the Recovery of Global and Regional Left Ventricular Function: Final 2-Year Analysis. Circulation Research. 2017. Ref.: https://goo.gl/pSRHsb

18. Benetti F, Peñherrera E, Maldonado T, Vera YD, Subramanian V, et al. Direct Myocardial Implantation of Human Fetal Stem Cells in Heart Failure Patients: Long-term Results. The Heart Surgery Forum. 2010; 13: 31-35. Ref.: https://goo.gl/gsu9jR 